\title{
5. The impact of active labour market policies on employers' evaluation of young unemployed: a comparison between Greece and Norway ${ }^{1}$
}

\section{Dimitris Parsanoglou, Aggeliki Yfanti, Christer Hyggen and Lulu P. Shi}

\section{INTRODUCTION}

According to the European Commission (2016), 'the main goal of active labour market policies (ALMPs) is to increase the employment opportunities for job seekers and to improve matching between jobs (vacancies) and workers (i.e. the unemployed)'. However, the effects of ALMPs on (re-) employment for young people are mixed and may well be affected by the general macroeconomic conditions and functioning of labour markets. As the head of the Youth Employment Programme at the International Labour Office has admitted, 'ALMPs cannot solve structural problems that require other types of policies, neither can they create jobs, particularly during periods of slack demand' (Rosas, 2015).

In this chapter we examine two extreme cases in Europe - Greece and Norway - with regard to both their macroeconomic conditions and the structure/functioning of their labour markets. Our aim is to explore the possible moderating impact of national contexts on the effects of participation in ALMPs on young people's employment probabilities (or rather on evaluations of such young people by employers). More precisely, we explore how employers evaluate participation in work training when rating candidates for a job and in the final selection between the best-rated candidates. Simulating the first phase of a real hiring process, an analysis of recruiters' evaluations of vignettes representing applicants' CVs is performed.

1 Acknowledgement: This study was co-funded by the Swiss State Secretariat for Education, Research and Innovation SERI (grant no. 15.0089) as part of the Horizon 2020 project 'Negotiating early job insecurity and labour market exclusion in Europe - NEGOTIATE'. 


\section{SCARRING EFFECTS OF UNEMPLOYMENT AND ACTIVE LABOUR MARKET POLICIES}

Persisting consequences of employment instability and unemployment have come to be known in the literature as scarring effects. Different theoretical explanations have been proposed to frame and explain such effects. Both demand- and supply-side factors may be seen as driving mechanisms of scarring (Helbling et al., 2016). In order to overcome the supply-side bias in research on the negative consequences of unemployment, we examine the role that employers play in the inclusion and exclusion of young adults who have experienced early job insecurity in the labour market. ${ }^{2}$ The impact of education, labour market conditions and employment policies on employer behaviour are of special interest in understanding the kinds of job biographies recruiters are looking for, as well as candidates' experiences that are viewed with caution.

One of the basic problems employers face during recruitment is the limited amount of accessible information they have on job applicants. Within a short space of time and with limited resources, recruiters try to find out as much as possible about the job candidates' productivity. During the first stage of the hiring process, employers often must rely entirely on limited information extracted from CVs. The questions regarding what sort of information they draw from the CVs to predict the suitability of the candidates for a specific position and how they interpret this information have engendered many studies in the social sciences building on different theoretical concepts and frameworks, notably human capital theory, job market signalling theory and employer discrimination theory (Helbling et al., 2016).

According to human capital theory, recruiters seek to know what the applicant's performance at work is like, including his/her skills and productivity; that is, all the attributes and properties often referred to in the literature as human capital (Becker, 1964, 1993). The acquirement and enhancement of human capital takes place during education and at work. Similarly, experiences of unemployment can be understood as foregone chances of human capital accumulation or as loss of previously earned skills and knowledge (Arulampalam et al., 2000). Frederiksen et al. (2013) have found that the duration of previous employment is an important indicator for human capital accumulation, simply because the longer the duration, the more time the worker has had to accumulate skills. Besides the duration of employment, recruiters are also interested in the quality

2 For a discussion of the concept of early job insecurity, see Dingeldey et al. (2015) and Hvinden et al. (Chapter 1 in Volume 1). 
of prior work experience. The skills considered the most valuable for organizations are work-specific skills; that is, whether the candidate has worked in the same or in a comparable occupational field before and/or has acquired the appropriate skills during education. Hence, depending on what unemployed people are doing during unemployment, human capital theory would presume that an increase in the duration of unemployment leads to decreased individual productivity, since long spells of unemployment might mean that an applicant had less time to acquire skills and knowledge. Lengthy unemployment might also suggest that candidates who have been educated and/or have worked in occupational fields irrelevant to the specific vacant job position are less well equipped with work-specific human capital. Accordingly, both experiences of unemployment and mismatch of job and education can be interpreted by employers as risks for productivity, likely resulting in an unsuccessful job application, unemployment and individual scars (Helbling et al., 2016). ALMPs, like training programmes, are designed to counteract human capital depreciation during unemployment. Building on human capital theory, participating in training programmes or in other types of ALMPs during unemployment - as opposed to being inactive - should have a positive effect on the evaluation of the candidate.

Obtaining information about applicants' true capabilities is costly, so recruiters often rely on the most visible - albeit sometimes superficial hints that can be extracted from CVs. This information can be classified into two categories: the unalterable attributes, such as gender or ethnicity - what Spence (1973) calls indices - and signals, which in contrast can be actively created by individuals, such as education and employment experiences. Educational credentials, school grades, company names of previous employers, but also gaps in CVs or participation in labour market measures can all serve as signals. In line with human capital theory, signalling theory suggests that spells of unemployment can signal a worker's low productivity and a deterioration of their motivation, behaviour and skills (Atkinson et al., 1996). Although employers do not systematically reject people with a history of unemployment, they are more careful about whether they hire them or not with a view to avoiding the potential risk of an unprofitable company investment (Helbling and Sacchi, 2014). In many cases they are more likely to opt for the more secure route by hiring people with a 'safe' biography - if the candidate pool allows for this - or preferring not to hire anybody at all rather than risking disrupting the workplace (Devins and Hogarth, 2005).

Other authors are more optimistic about what unemployment may signal. Ma and Weiss (1993) studied people who voluntarily prolong their unemployed status and reject taking the next best job. This can occur 
when the proposed wage is below the lowest wage that the applicant would accept - the so-called reservation wage - or when taking the job would decrease his/her chances of finding future employment. In this light, it seems plausible that employers do not necessarily always consider unemployment or even prolonged periods of unemployment as a bad signal; instead they might differentiate between individual cases. According to McCormick (1990), former job experiences are stronger and more reliable signals for productivity than the duration of unemployment spells. Eriksson and Rooth (2014) suggest that the strength of the negative signal of experiences of unemployment firmly depends on the duration of the spell and whether work experience follows the periods of inactivity. In a field experiment they found evidence that unemployment needs to last for at least nine months for recruiters to perceive it as a bad signal. Furthermore, they suggest that the effect of an unemployment spell can be neutralized by subsequent work experiences.

Furthermore, the rank and quality of the position an employer is recruiting for also plays a major role. Employers who are recruiting for positions that require low or medium skills are more likely to reject applicants who have experienced unemployment, while recruitment for positions that require higher skills is accompanied by more tolerance towards applicants with experiences of unemployment, even when these were of lengthy duration.

Whether unemployment is perceived as a negative signal depends not least on the reason for the job displacement. Even though signalling theory adds valuable additional explanations to human capital theory in terms of understanding scarring effects from an employer's perspective, neither economic theory considers the social embeddedness of the hiring process. Sociological theories, on the other hand, take the social background of both job applicants and companies into account, against which signals must be analysed, and upon which their meanings may vary. In order to explain how recruiters gather and evaluate information on applicants' social backgrounds, discrimination theories consider the embeddedness of signals in a social context (Imdorf, 2017). In theory, the signals sent by work-training participation should be positive, reflecting activity and motivation. However, the content and intensity of the activities during participation are still unknown to the employer.

Therefore, theories of discrimination help us understand how employers can read identical signals differently by taking information on the applicants' social backgrounds into account. It is sometimes the case that two individuals with the same educational credentials or identical work experience are treated differently. This may happen if these two individuals belong to different social groups that are believed to be equipped with 
unequal abilities. Depending on the social backgrounds of the applicants, their previous experiences might be interpreted differently. The taste-based theory of discrimination (Becker, 1971) argues that employers who have a taste for discrimination would be willing to sacrifice profit for choosing a less productive worker over a more capable one because the latter possesses traits unrelated to productivity with which the employer does not feel comfortable.

The statistical theory of discrimination (Phelps, 1972), on the other hand, is based on the premise that employers are rational individuals whose actions are driven by profit maximization. The reason why they exert discrimination is because of their flawed observations and beliefs about members of specific groups. If employers assume the proportion of productive workers to be relatively small in certain groups, they might be unwilling to spend time and money to find out the true abilities of somebody who belongs to one of these groups and might prefer to let possible talents go undiscovered.

To sum up, a prior belief about a certain group can determine a recruiter's subsequent belief about the productivity of a worker from that group (Mishra, 2003). Signals can become unclear ('noisy') in interaction with class or ethnic background (Seibert and Solga, 2005). The presumption of group homogeneity procures advantages for some and disadvantages for others who belong to other groups. Unlike human capital theory (which assumes that recruiters act rationally and only hire the applicants with the highest known productivity) and unlike signalling theory (which ignores the social contexts in which employers and jobseekers are embedded), discrimination theories suggest that one pay attention to the perception of people in relation to their social and cultural backgrounds. Discrimination takes place in various shapes. The most obvious and strongest reaction is to not give the applicant a job at all. Another way to enact discrimination is to measure situations in which there is a mismatch between an individual's job and education. Higher qualifications might be required from an applicant from a discriminated group in order to prove her/his skills, whereas a recruiter might accept another application that signals a lower qualification from an individual from a group that is not discriminated. Overqualification is common amongst immigrant workers, whose credentials are downgraded when they apply for jobs in a host country (Andersson et al., 2012). Participating in a work-training programme is not equal to belonging to a social group, nonetheless employers may believe that work-training participants share some unobserved negative qualities (statistical discrimination), rendering them more likely to evaluate participants negatively.

To summarize, the impacts of attributes such as educational attainment, unemployment, situations where there is a mismatch between an 
individual's education and job, and gender are well known in the research literature. Some authors have examined scarring effects by concentrating on the duration of unemployment (Atkinson et al., 1996; Cockx and Picchio, 2013; McCormick, 1990), while others have measured its impacts by contextualizing unemployment more specifically with regard to employment history (Eriksson and Rooth, 2014; Frederiksen et al., 2013). Others again have used education as a benchmark (Diem and Wolter, 2014; Rosenbaum et al., 1990). Little research has been done on the possible scarring effects of measures invented to counteract the negative consequences of unemployment. An exception is the factorial survey experiment conducted with managers of hotels in Switzerland (Liechti et al., 2017), which focused on the signalling effect of participation in labour market programmes. The experiment showed that participation in such programmes can be assessed either positively or negatively by employers, depending on the candidate's distance from the labour market: candidates who are more distant from the labour market receive a better evaluation if they have participated in a programme, while for 'stronger' candidates, participation can act as a relative stigma in the eyes of employers.

In the cases of Greece and Norway examined here, we find differentiated effects of unemployment and participation in ALMPs. These differentiations are probably linked to differences in both the structure of the labour markets and the macroeconomic contexts in the two countries.

\section{MACROECONOMIC CONTEXT, RECRUITMENT PRACTICES AND REGULATORY FRAMEWORK}

National labour markets are shaped by specific economic conditions and political regulations. We assume that different economic contexts and institutional frameworks are not only associated with insecurity regarding employment (Chung and Van Oorschot, 2011), rather also with countryspecific recruitment behaviour on the part of firms, especially when we compare two countries with such different structural and institutional backgrounds as Greece and Norway. The general economic situation of a country, and especially that within specific industries, is relevant for a company's risk assessment when hiring young employees (Grotti et al., 2018). Gangl (2002) was able to show not only that the risk of unemployment closely follows the cyclical changes of economic conditions, but also that the lowest qualified are affected most heavily by such changes. Hence the risk assessment of companies during the recruitment process is more cautious when the economic situation is difficult. We can therefore assume that job candidates' experiences of unemployment or occupation 
in insecure jobs might be exacerbated during the hiring process in difficult economic contexts.

The gross domestic product (GDP) per capita is an indicator of a country's economic performance. An alternative measure that captures firms' hiring and firing behaviour more directly is the (youth) unemployment rate, that is, the share of the (young) labour force that is without work but is available for and seeking employment.

For the last few decades Norway has had a significantly higher GDP per capita than Greece (for details, see Figure 5A.1 in the Appendix, this chapter). The two countries also differ with regard to unemployment rates, with Greece showing significantly higher and growing figures - particularly in the years following the 2008 financial crisis - whereas the rates in Norway are much lower and have been rather unaffected by the crisis (for details, see Figures 5A.2 and 5A.3 in the Appendix, this chapter).

Accordingly, if we only consider the national economic situations of the two countries, we can expect young people who have experienced job insecurity to have better chances of being hired in Norway than in Greece. To sum up, Norway combines a good economy with low unemployment rates, while Greece displays lower economic performance and high unemployment rates, particularly for young people. Therefore, we expect the two countries' contexts to have different impacts on the meaning and significance of individual job insecurity for a person's chances of being recruited for a new job.

\section{ALMPS IN GREECE: STRUGGLING WITH STRUCTURAL SHORTCOMINGS}

Profound changes in labour relations and labour rights in Greece started back in 2010 as part of fiscal-discipline policies following the sovereign debt crisis of 2009. These reforms were imposed by the structural adjustment programmes accompanying the Memoranda of Understanding between Greece and its creditors (for further details, see Karamessini et al., 2016a). Changes have mainly focused on the expansion of flexible forms of employment as against steady and full-time employment, on more flexible working hours, on liberation and facilitation of layoffs, and on changing the way wages are determined through collective bargaining (Kouzis, 2014).

Some of the changes in Greek labour legislation have particularly affected young people. The definition of a specific minimum wage for youth aged under 25 and apprentices, which was reduced in 2012 by 32 per cent in relation to the national minimum wage, has certainly had a 
significant impact on young workers' lives. The minimum wage floor was set at 586.08 euros for employees over the age of 25 and at 510.95 euros for those aged under 25. Furthermore, the trial period for the newly recruited has been extended from two to 12 months, and employers are generally facilitated in hiring workers on fixed-term or part-time contracts, as well as replacement workers through employment agencies. Those who have entered the labour market since the changes have been greatly affected by the extension of flexible forms of employment. It is telling that the parttime employment rate has almost doubled since 2008 in the age category 15-25 (from 13.4 per cent to 21.1 per cent), while for the category 25-29 it has increased from 6.1 per cent to 12.2 per cent. In the Greek case, parttime employment is hardly voluntary; most part-time employees have no other option, rather they accept this form of employment given the lack of full-time employment: 63 per cent in the age category 15-24 and 74.4 per cent in the category 25-29 reported that they are working part time against their will (Petmesidou and Polyzoidis, 2015).

It is, however, important to note that in Greece, even before the current financial and economic crisis, education-to-work transitions appeared quite problematic. According to a survey on the participation in employment of university degree-holders conducted during the years 2005-06, 84 per cent of the respondents were working five to seven years after their graduation, but 45 per cent of these were on fixed-term, part-time or project-based contracts (Karamessini et al., 2008).

In Greece, labour policies targeting youth had for some time showed a focus on activation measures. Before 2013 policies on work-study balance included an allowance for students during exams and subsidization of internships for students in universities of applied sciences that covered 50 per cent of the cost. Since 2013 a dialogue has been launched on the formation of an institutional framework for internship as part of the European Quality Framework of Internship, but also of the national strategy for the improvement of vocational education and training. These institutional initiatives were funded partly by the Greek Youth Guarantee programme.

Vocational training and its incorporation in the general educational system has not really been very high on the political agenda or visible in the design of main policy objectives. The main goal is its adjustment to labour market needs. Policies and measures that encourage young people who abandoned education to return have been relatively weak. The only exception was the establishment of 'second-chance schools', which was, however, a fragmented initiative that had low impact on the target group. When it comes to employment policies, one can see that vocational training has diachronically played an important role, since it is usually the most significant part of ALMPs. Voucher programmes for participation in vocational 
education and training have been significantly extended in recent years. These programmes are implemented by the Ministry of Labour on the basis of geographical criteria, that is, according to local unemployment rates or level of economic development, but they also target specific groups of redundant workers, for instance those from big companies or from specific sectors that have been affected by the economic crisis.

To sum up, in Greece policies regarding school-to-work transitions are weak. Their ineffectiveness is demonstrated by the extremely low probability of school-leavers finding employment one year after graduation: in Greece in 2013, the probability of finding employment was 19 per cent, of being unemployed 56 per cent and of being inactive 25 per cent (Karamessini et al., 2016b). Even if the Youth Guarantee programme seemed to trigger a dialogue on the obligation of all relevant stakeholders to establish a sort of social contract for the enhancement of young people's probabilities of finding a place in the labour market or in education, the outcomes of the programme up until now have been relatively poor. While there has certainly been a significant impact of such actions on the possibility of acquiring some work experience for those who wish to enter the labour market, Greece's youth unemployment rate still remains the highest in the EU, (involuntary) flexible forms of employment keep growing at the expense of steady and full employment, and wages remain low. In other words, it seems that the financial and economic policies in Greece and the low demand in the Greek labour market are undermining any initiative towards an increase in youth employment.

\section{ALMPS IN NORWAY: A LONG TRADITION WITH AMBIGUOUS RESULTS}

Young unemployed and dropouts from upper-secondary school in Norway primarily participate in one of three measures: work training, wage subsidies and different kinds of training aimed at upskilling or enabling participants for employment. Amongst these three, the most widely used measure is work training (Von Simson, 2012: 80). Administered by the Norwegian Labour and Welfare administration (NAV), this measure gives all unemployed people the opportunity to gain work experience for up to one year, being placed in an ordinary company or business while being followed up by their NAV supervisor (NOU 6, 2012).

For the age group 16-19, 70 per cent of participants in ALMPs in 2016 were in work training. Out of the age group 20-24, 46 per cent of ALMP participants were participating in work training (NAV Statistics, 2016). The average share for all age groups in 2016 was 30 per cent. The main 
reason for this high percentage is the goal of the Youth Guarantee that seeks to give this age group practical work experience before (re-)entering higher education or work (Strand et al., 2015). Work training is by far the most widely used labour market measure for the young in Norway (NAV Statistics, 2016). Overall, when studying the effect of labour market measures on youth in Norway, work training is the most important measure to understand.

Work training has a long history as a labour market measure in Norway (Zhang, 2016: 46). It involves the unemployed participant being placed in an ordinary workplace. The participant is supposed to formulate a plan in cooperation with her NAV supervisor regarding what is to be achieved during the work-training period. The employer commits to mentoring the newcomer in a way that make the participant better qualified (Zhang, 2016: 46).

Despite being the most widely used labour market measure, research concludes that work trainings have only small or negative effects on combatting youth employment. First, Von Simson's (2012) research comparing the effects of private intermediary firms with NAV's work-training measure for upper-secondary school dropouts concludes that taking part in NAV-organized work trainings results in 30 per cent less probability of becoming employed during the measure. There is no increased probability of employment after the measure.

Second, Hardoy (2005) reaches a similar conclusion using older data from 1989 to 1993. Compared to Von Simson, Hardoy looks at youth up to the age of 25 and concludes that the work trainings only work positively for girls aged 16-20. Third, using an event-history analysis on everyone registered as unemployed in the time span 2003 to 2012, Zhang (2016) concludes that work trainings have a minimal effect on reducing unemployment. It is worth noting that Zhang does not separate youth as one group from his data. Overall, research tends to conclude that NAV's work training has at best negligible effects on reducing youth unemployment.

\section{SURVEY AND EXPERIMENT DESIGN}

How the different national contexts ultimately impact on the chances of young adults with insecure past job experiences being hired for new jobs, and which context ultimately proves to be the most relevant, remain empirical questions. In the second part of this chapter we outline our methodological and empirical approach, which is aimed at answering the following research question: How do employers use information on participation in ALMP measures in relation to education, gender and 
unemployment in their assessment of written job applications in different economic and institutional contexts?

In order to study the scarring effects of insecure job experiences induced by employers, we apply a straightforward methodological design - a multi-dimensional vignette experiment integrated in a web-based employer survey. The vignettes simulate hypothetical job candidates who differ by gender, education and experience of (un-)employment and participation in work training. A main aim of our research design was to capture the complexity of hiring decisions and to test multiple potential scarring factors at the same time. Since the dimensions are orthogonal to each other - in other words, the levels of one dimension can vary independently of the levels of other dimensions - it is possible to calculate the influence of each of the dimensions on the outcome (Auspurg and Hinz, 2015). A multifactorial survey design therefore permits the analysis of the single and joint effects of several features of the job applicants on hiring decisions.

The main idea behind the factorial survey method is to present survey respondents with stimuli that resemble real-world evaluations and to force them to make trade-offs between several dimensions. The method is arguably better at enabling a more precise determination of the judgement principles that underlie evaluations than is possible using, for example, single-item questions (Auspurg and Hinz, 2015). The set-up of a factorial survey follows the guiding principles of experimental research. The stimuli are manipulated by the researchers and the outcome can be causally related to this manipulation. The factorial survey design combines the advantages of experimental and survey research. The experiments guarantee internal validity and the survey methodology allows for relatively cost-effective data collection reaching a heterogeneous population, thus also increasing its external validity (Hyggen et al., 2016).

A pre-test was performed to test the field access, response rates and the questionnaire in five occupational sectors. The sample size for the main data collection was established based on results from this pre-test. Real vacancies for occupations in five sectors - mechanics, finance, health, catering and information technology - were sampled during spring 2016 using online job portals. ${ }^{3}$ This choice enables the results to be close to the outcomes of the real hiring process.

A general strategy was applied for sampling. First, databases and communication channels for job advertisements covering the chosen occupa-

3 In Greece a total of 14 online job portals were used in sampling (with three of them, xe.gr, skywalker.gr and aggeliopolis.gr covering almost 80 per cent of the job vacancies that were retrieved), while in Norway the online portals used were nav.no and finn.no, which together cover 90 per cent of the positions publicly advertised in the country. 
tions and sectors were identified and analysed for structure and search opportunities. Second, channel-sensitive search algorithms designed to capture vacancies in the relevant occupations in the five sectors were applied. This included both text-based searches where the description exactly coincided with one of the labels of interest for the study and text-based searches where appropriate sub-categories from the full labels of offered positions in the sector were chosen. The third step consisted of sorting out identified vacancies that would not meet our criteria (for instance, vacancies requiring more than five years' professional experience). In most cases this was done through manual screening of the ads.

Based on contact information from the job advertisements, but also through phone calls in cases where email addresses were missing (particularly in Greece), the personnel responsible for recruiting for the position were contacted and invited to participate in an online survey. Participants in the survey were presented with an image of the sampled vacancy in order to link their responses directly to the hiring procedure for the sampled vacancy.

The online survey consisted of three parts. In the first part respondents were asked if the recruitment occurred externally by means of a professional personnel recruitment company and were then asked questions about the advertised job (e.g., workload, form of contract) and about the characteristics and requirements of the advertised position (e.g., required educational credentials and work experience, supervisory functions) beyond the information that was given in the advertised vacancy. It was further asked how difficult it was to find suitable candidates for the specific job that was being advertised and how urgent it was that the vacancy should be filled.

Following the first section of the survey, the respondents were asked to rate eight vignettes representing hypothetical job candidates' CVs that were shown to them one by one. ${ }^{4}$ The vignettes were shown in a graphical format so as to visualize (un)employment history and education. The vignettes (CVs) were designed to allow for a number of experimental variables:

- Gender (male/female);

- Timing of unemployment (immediately after graduation / between two previous jobs / ongoing when applying for new job);

- Duration of unemployment (0 months / 10 months / 20 months);

4 The initial design was to include ten vignettes for each respondent; however, a technical problem in the Greek online questionnaire - which included only eight vignettes - led the research team to decide to consider only the first eight vignettes evaluated in each country. 
- Education level (lower-secondary / upper-secondary / tertiary);

- Education type (specific to job advertisement / non-specific: retail sale);

- Employment experience (specific to job advertisement / retail sale / call-centre work); and

- ALMP participation during unemployment (PES employment programme in Greece and work training in Norway).

The first task for the respondents consisted in rating the likelihood of the illustrated candidate on the vignette being hired for the advertised position. The respondents rated the likelihood of being hired using a 10 -point scale ranging from $0=$ not likely to $10=$ very likely. The best-rated three vignettes entered the next round, where they were paired with one another. The respondents were asked to choose one preferred candidate for each pair (forced choice task). The vignette that was twice preferred was the winner. After the forced choice task, the respondents were asked to report what other information they would have liked to know about the candidates in addition to the limited dimensions of the vignettes.

The third part of the survey (following the vignette study) covered questions about the recruiting process and further questions on the characteristics of the advertised position (e.g., how and through which channels vacancies were communicated and who was involved in the recruitment process). The respective answers provide additional information on the various contexts and help us understand the vignette ratings. To find out how the recruitment process reflects organizational features, the questionnaire also included questions about the size of the organization, whether it was located in the public or the private sector, and what the economic outlook of the company was like. Finally, we collected personal data from the respondents (e.g., work experience, professional background, function, education, gender, age).

\section{RESULTS}

In our analysis we compare the two countries with regard to the assessment of participation in ALMPs by employers/recruiters. Descriptive results from the survey show variations in reservations between the two countries about hiring previously unemployed youth. In general, Norwegian recruiters seem to have more reservations about hiring a person who has been unemployed during the recent past; in Greece, on the contrary, reservations are limited - with the exception of the catering sector (Table 5.1). This might be explained by the fact that catering and tourism are generally 
Table 5.1 Would you have any reservations about hiring a person who has been unemployed during the last two years?

\begin{tabular}{lccccccc}
\hline & \multicolumn{3}{c}{ Greece } & & \multicolumn{3}{c}{ Norway } \\
\cline { 2 - 3 } \cline { 7 - 8 } & No & It depends & Yes & & No & It depends & Yes \\
\hline Mechanics & 38.9 & 53.8 & 7.3 & & 21.8 & 69.1 & 9.1 \\
Finance & 37.1 & 55.3 & 7.7 & & 19.0 & 67.1 & 13.9 \\
Health & 43.1 & 51.4 & 5.6 & & 8.7 & 74.2 & 17.0 \\
Catering & 35.3 & 47.9 & 16.8 & & 5.0 & 77.5 & 17.5 \\
IT & 42.3 & 48.7 & 9.1 & & 20.7 & 58.6 & 20.7 \\
Total & 39.2 & 51.5 & 9.3 & & 13.2 & 70.7 & 16.1 \\
\hline
\end{tabular}

Source: Author's interpretation.

sectors with a relatively high demand for labour because of the importance of the industry for the Greek economy at large. In Norway, on the other hand, the mechanics sector is that where the reservations of recruiters are most moderate.

The results from the survey also reveal great differences between the two countries in regard to employers' assessment of enrolment in employment schemes for the unemployed (Table 5.2). In general, Norwegian employers/recruiters are more prone to believing that participation in ALMP schemes decreases people's chances of getting hired than Greek employers. In the case of finance, in both countries enrolment in employment schemes has a potentially negative effect on recruiters' assessments, while in Norway the most negative effect is in the health sector. The sectors where enrolment in employment schemes is mostly perceived as an advantage for candidates, on the other hand, are mechanics in Greece and catering in Norway; whether these specificities are based on sector particularities or highlight certain trends are questions to be further explored in additional research.

In order to examine the effect of participation in ALMP measures on recruiters' ratings and choices, we employed fixed-effects multi-level linear regression models (Auspurg and Hinz, 2015). To test our hypothesis on the positive effect of participation in ALMP, we estimated country-specific multi-level regression models (see Imdorf et al., Chapter 5 in Volume 1, for detailed model specifications).

As Figure 5.1 shows, there is a general divergence between the two countries regarding the effect of participation in ALMPs on recruiters' evaluations (also see Figure 5A.4 in the Appendix, this chapter, for results on gender). While in Greece participation in an ALMP has a positive 


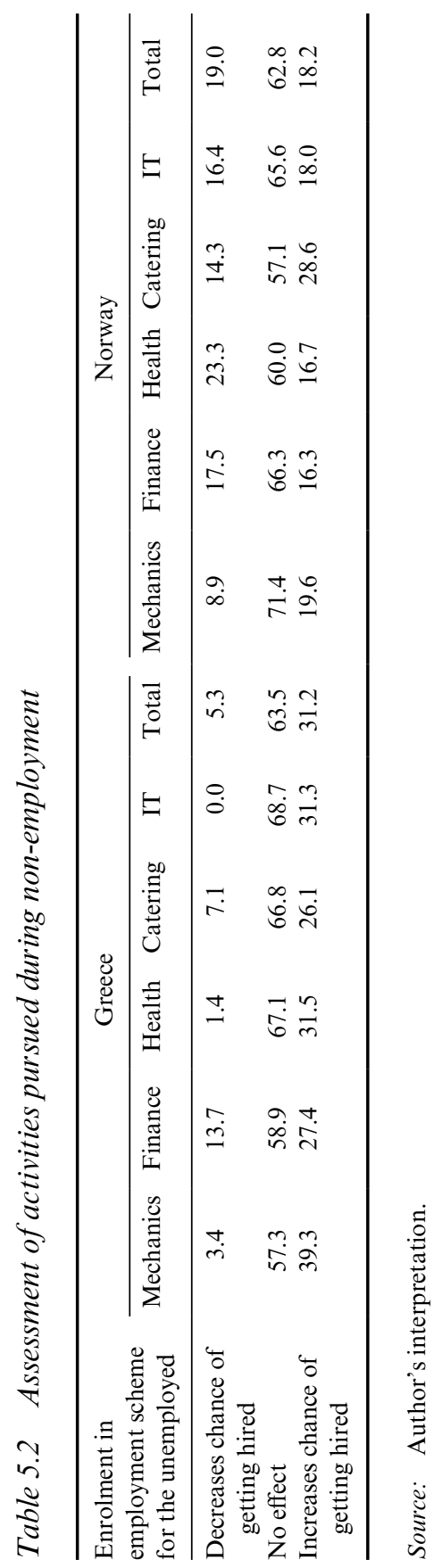

104 


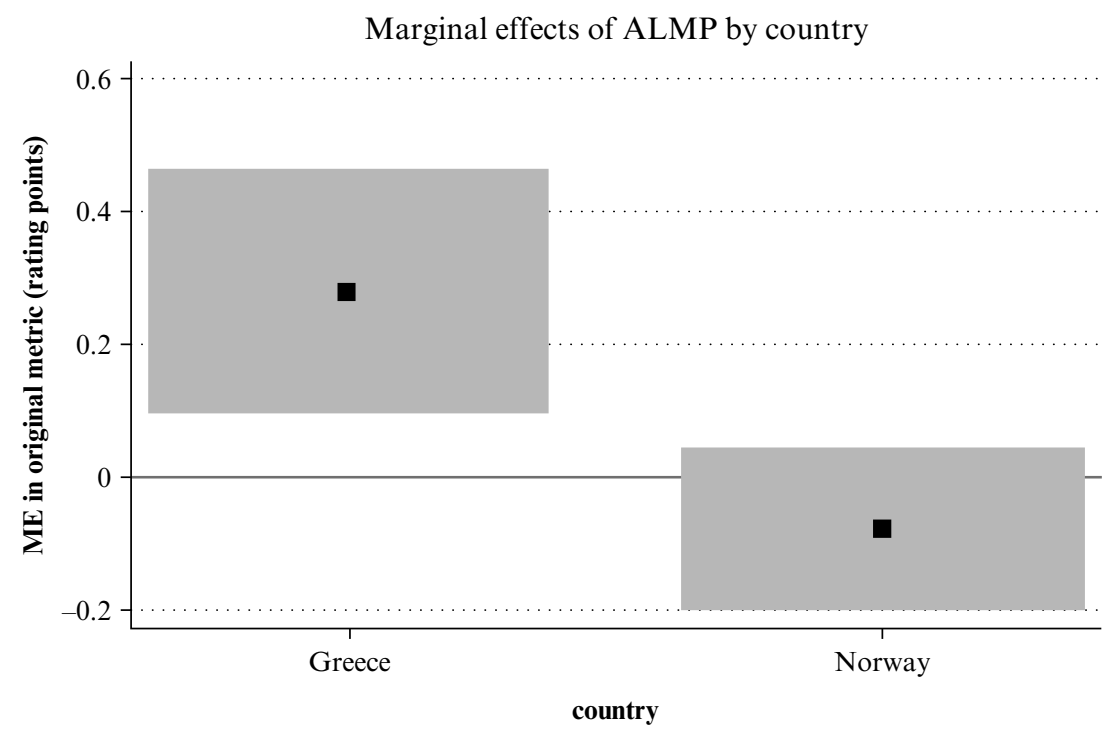

Source: Author's interpretation.

Figure 5.1 Marginal effects of ALMP participation on recruiter ratings, by country

effect, in Norway participating in work training during unemployment, all things being equal, has either no effect or negative effects on the likelihood of being hired. The analyses also reveal that gender matters only in Greece: the positive effect of participation in ALMPs is more significant in the case of male than of female candidates. In Norway there are no observed gender differences.

If we look at each country separately and at the effect of participation in ALMPs across sectors and gender, we can see in Figure 5.2 that in Greece gender differentiations exist mainly in mechanics and finance: in mechanics there is a positive effect for male candidates, while in finance the situation is reversed. In the other sectors the effect is equally neutral for both sexes.

In Norway participation in ALMPs seems to have a relatively neutral or negative effect on recruiters' assessments, with the slight exception of the catering sector, where male candidates' participation in ALMPs is evaluated more positively than participation by female candidates.

Divergences are observed also when it comes to education level and participation in ALMPs (Figure 5.3). In Greece the higher the level of 


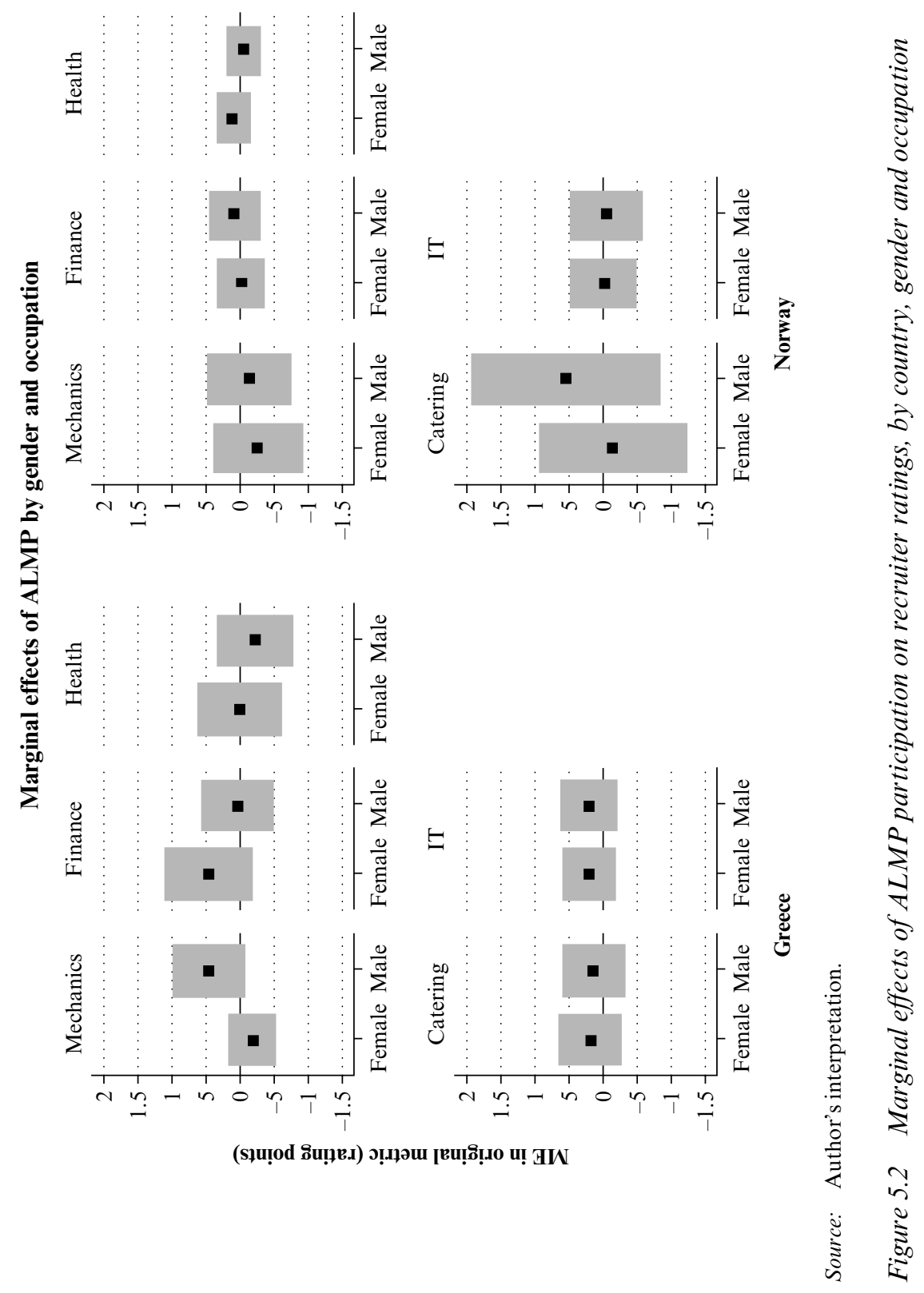




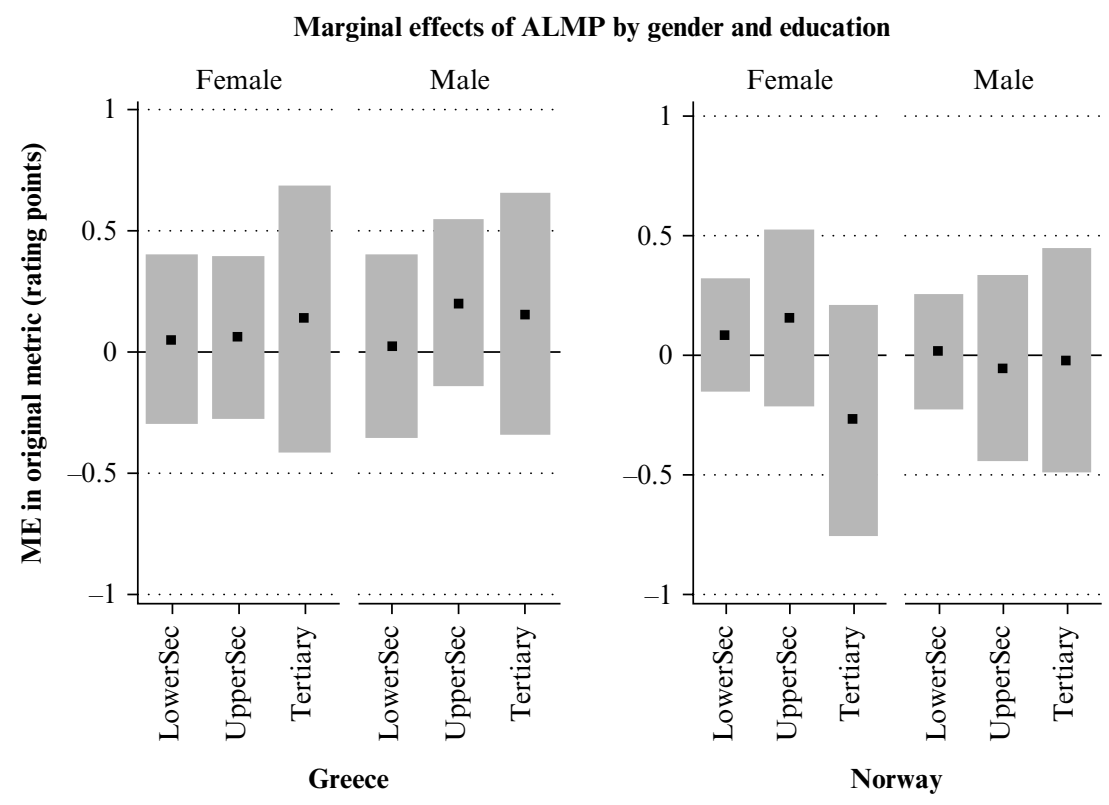

Source: Author's interpretation.

Figure 5.3 Marginal effects of ALMP participation on recruiter ratings, by country, gender and education

education attained by a candidate who has participated in an ALMP, the more positive is the effect on his/her chances of being hired. For male candidates there is a positive effect - slightly more significant - also for those who have completed upper-secondary education.

In Norway the case seems to be inversely proportional, that is, the higher the education level, the less positive is the effect. This is more pronounced in the case of female candidates who have completed tertiary education; for this specific group it seems that participation in ALMPs has a negative effect during the evaluation of $\mathrm{CVs}$ by recruiters/employers.

\section{CONCLUSIONS}

For the last few decades ALMPs have been the guiding principle of policies aimed at reducing unemployment and job insecurity, particularly amongst the young. There has been a certain unanimity on this across the OECD countries, which have in one way or another adopted this approach in 
designing and implementing relevant policies. Nevertheless, evidence shows that participation in ALMPs does not necessarily have a positive impact on someone's chance of finding a job. As other researchers have demonstrated (Liechti et al., 2017), 'different ALMPs entail different substantial and signalling effects depending on the job and characteristics of the candidate'.

More specifically, our findings show that the scarring effects of unemployment are more pronounced in countries where the macroeconomic context is positive and unemployment rates - including the youth unemployment rate - are low. What is also significant is that participation in ALMPs is not perceived in such a positive way in these cases. Our study shows that participating in ALMPs is perceived more positively in a context of high unemployment, such as in Greece, while it might have a negative effect in a context where labour demand is high, such as in Norway.

Coming back to our initial theoretical considerations, we could suggest that our findings somehow qualify hypotheses formulated within both human capital and signalling theories. Without neglecting findings from previous research that has demonstrated the significance of skills acquirement or of inactivity/unemployment spells in one's professional trajectory, our research adds and highlights the significance of the macroeconomic context and the institutional framework of both the labour market and vocational education and training. Divergences between countries with substantially different characteristics regarding economic and labour market contexts are evident in the ways in which recruiters and employers evaluate young candidates' experiences. In this sense this chapter contributes to the field by identifying divergences and national specificities regarding recruiters' evaluation of participation in work training as one credible mechanism behind results found in other studies. Contrary to the dominance of ALMPs as the most plausible way to deal with unemployment and the risk of reduced employability, our findings call for rethinking and, most importantly, for contextualizing ALMPs by taking into account national and sectorial specificities.

\section{REFERENCES}

Andersson P, Gupta ND and Wadensjö E (2012) Overeducation among immigrants in Sweden: Incidence, wage effects and state-dependence. IZA Discussion Paper no. 6695. Bonn: Institute for the Study of Labor.

Arulampalam W, Booth AL and Taylor MP (2000) Unemployment persistence. Oxford Economic Papers 52(1): 24-50.

Atkinson J, Giles L and Meager N (1996) Employers, recruitment and the unemployed. IES Report no. 325. Brighton, UK: Institute for Employment Studies, Sussex University. 
Auspurg K and Hinz T (2015) Factorial Survey Experiments. London, UK: Sage.

Becker GS (1964) Human Capital: A Theoretical and Empirical Analysis with Special Reference to Education. Chicago, IL: University of Chicago Press.

Becker GS (1971) The Economics of Discrimination. Chicago, IL: University of Chicago Press.

Becker GS (1993) Human Capital: A Theoretical and Empirical Analysis, with Special Reference to Education, 3rd ed. Chicago, IL: University of Chicago Press.

Chung $\mathrm{H}$ and Van Oorschot W (2011) Institutions versus market forces: Explaining the employment insecurity of European individuals during (the beginning of) the financial crisis. Journal of European Social Policy 21(4): 287-301.

Cockx B and Picchio M (2013) Scarring effects of remaining unemployed for longterm unemployed school-leavers. Journal of the Royal Statistical Society: Series A (Statistics in Society) 176(4): 951-80.

Devins D and Hogarth T (2005) Employing the unemployed. Some case study evidence on the role and practice of employers. Urban Studies 42(2): 245-56.

Diem A and Wolter SC (2014) Overeducation among Swiss graduates: Determinants and consequences. Journal for Labour Market Research 47(4): 313-28.

Dingeldey I, Hvinden B, Hyggen C, Schoyen MA and O'Reilly J (2015) Understanding the consequences of early job insecurity and labour market exclusion: The interaction of structural conditions, institutions, active agency and capability. NEGOTIATE Working Paper no. 2.1. https://negotiate-research.eu/files/2015/04/ NEGOTIATE-working-paper-no-D2.1-1.pdf (accessed 28 May 2018).

Eriksson S and Rooth D-O (2014) Do employers use unemployment as a sorting criterion when hiring? Evidence from a field experiment. American Economic Review 104(3): 1014-39.

European Commission (2016) European Semester: Thematic factsheet - Active labour market policies. https://ec.europa.eu/info/strategy/european-semester/the matic-factsheets/labour-markets-and-skills_en (accessed 28 May 2018).

Frederiksen A, Ibsen R, Rosholm M and Westergaard-Nielsen N (2013) Labour market signalling and unemployment duration: An empirical analysis using employer-employee data. Economic Letters 118(1): 84-6.

Gangl M (2002) Changing labour markets and early career outcomes: Labour market entry in Europe over the past decade. Work, Employment and Society 16(1): 67-90.

Grotti R, Russell H and O'Reilly J (2018) Where do young people work? In: O'Reilly J, Leschke J, Ortlieb R, Seeleib-Kaiser M and Villa P (eds) Youth Labor in Transition. Inequalities, Mobility, and Policies in Europe. New York: Oxford University Press, Chapter 2.

Hardoy I (2005) The impact of multiple labour market programs on multiple outcomes. Labour. The Review of Labour Economics and Industrial Relations 19(3): 425-67.

Helbling LA, Imdorf C, Ayllón S and Sacchi S (2016) Methodological challenges in the study of scarring effects of early job insecurity. NEGOTIATE Working Paper no. 6.1. https://negotiate-research.eu/files/2015/04/NEGOTIATE-working-paperno-D6.1-Methodological-challenges-in-the-study-1.pdf (accessed 28 May 2018).

Helbling LA and Sacchi S (2014) Scarring effects of early unemployment among young workers with vocational credentials in Switzerland. Empirical Research in Vocational Education and Training 6(12).

Hyggen C, Imdorf C, Parsanoglou D, Sacchi S, Samuel R, Stoilova R, Shi LP, Yfanti A and Yordanova G (2016) Understanding unemployment scars: A vignette 
experiment of employers' decisions in Bulgaria, Greece, Norway and Switzerland. NEGOTIATE Working Paper no. 7.2. https://negotiate-research.eu/files/2015/04/ NEGOTIATE-working-papers-no-D7.2.pdf (accessed 28 May 2018).

Imdorf C (2017) Understanding discrimination in hiring apprentices: How training companies use ethnicity to avoid organisational trouble. Journal of Vocational Education and Training 69(3): 405-23.

Karamessini M, Kominou K and Papazachariou A (2016a) Institutional determinants of early job insecurity in nine European countries. National Report Greece for NEGOTIATE Working Paper no. 3.4. See https://negotiate-research.eu.

Karamessini M, Symeonaki M and Stamatopoulou G (2016b) The role of the economic crisis in determining the degree of early job insecurity in Europe. NEGOTIATE Working Paper no. 3.3. https://negotiate-research.eu/files/2015/04/ NEGOTIATE-working-paper-D3.3.pdf (accessed 19 May 2018).

Karamessini, Vitoratou S, Gazon E and Moustaki I (2008) The Absorption of University Graduates in the Labour Market. Athens: Dionikos.

Kouzis I (2014) Labour in the vortex of economic crisis and memoranda. In: Zamparloukou and Kousis (eds) Dimensions of the Current Crisis: Society and Crisis. Athens: Pedio, pp. 231-46.

Liechti F, Fossati, F, Bonoli G and Auer D (2017) The signalling value of labour market programmes. European Sociological Review 33(2): 257-74.

Ma CA and Weiss AM (1993) A signaling theory of unemployment. European Economic Review 37(1): 135-7.

McCormick B (1990) A theory of signalling during job search, employment efficiency and 'stigmatised' jobs. Review of Economic Studies 57(2): 299-313.

Mishra A (2003) A theory of discrimination based on signalling and strategic information acquisition. Working Paper. Dundee, UK: University of Dundee, Department of Economics.

NAV Statistics (2016) Arbeidssøkere og stillinger. Tiltaksdeltakere [Jobseekers and jobs. Participants in measures]. https://www.nav.no/no/NAV+og+samfunn/Statis tikk/Arbeidssokere+og+stillinger+-+statistikk/Tiltaksdeltakere (accessed 28 May 2018).

NOU 6 (2012) Arbeidsrettete tiltak [Work-oriented measures]. https://www.regjerin gen.no/contentassets/f2ce6d22c3914e7b89d15db41285cf85/no/pdfs/nou20122012 0006000dddpdfs.pdf (accessed 28 May 2018).

Petmesidou M and Polyzoidis P (2015) What policy innovation for youth in the era of prolonged austerity? The case of Greece. OSE Research Paper no. 20. Brussels: European Social Observatory.

Phelps ES (1972) The statistical theory of racism and sexism. American Economic Review 62: 659-61.

Rosas G (2015) Active labour market policies: What works for youth? Presentation at: Piloting Youth Guarantee on the Ground: Experiences from the European Parliament Preparatory Action. Brussels, 8 May.

Rosenbaum JE, Takehiko K, Settersten R and Maier T (1990) Market and network theories of the transition from high school to work: Their application to industrialized societies. Annual Review of Sociology 16: 263-99.

Seibert H and Solga H (2005) Gleiche Chancen dank einer abgeschlossenen Ausbildung? Zum Signalwert von Ausbildungsabschlüssen bei ausländischen und deutschen jungen Erwachsenen [Equal opportunities thanks to completed training? On the signalling value of completed training in non-German and German young adults]. Zeitschrift für Soziologie 5(34): 364-82. 
Spence M (1973) Job market signaling. Quarterly Journal of Economics 87(3): $355-74$.

Strand A-H, Bråthen M and Grønningsæther A (2015) Nav-kontorenes oppfølging av unge brukere [The Norwegian Labour and Welfare Organisation (NAV)'s supervision of young clients]. http://www.fafo.no/index.php/nb/zoo-publikasjoner/ fafo-rapporter/item/nav-kontorenes-oppfolging-av-unge-brukere (accessed 18 May 2018).

Von Simson K (2012) Veier til jobb for ungdom uten fullført videregående opplæring. Kan vikarbyråer og arbeidsmarkedstiltak lette overgangen fra utdanning til arbeidsliv? [Paths to work for youth with incomplete upper-secondary education. Can temporary employment agencies and labour market measures facilitate the school-to-work transition?] Søkelys på arbeidslivet 29(1-2): 76-96.

Zhang T (2016) Virker arbeidspraksis i ordinær virksomhet etter sitt formål? [Does the work training scheme in the ordinary sector work?] Søkelys på arbeidslivet 33(1-2): 45-65. 


\section{APPENDIX}

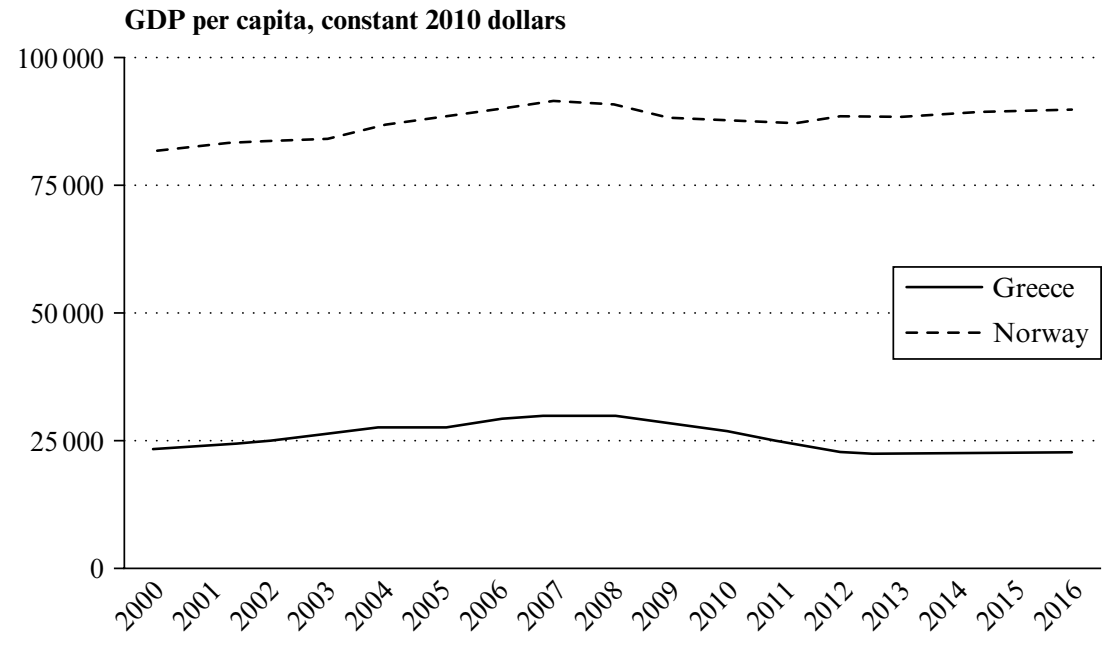

Source: TheGlobalEconomy.com, World Bank.

Figure 5A.1 GDP per capita in constant 2010 US\$, Greece and Norway, 2000-16 


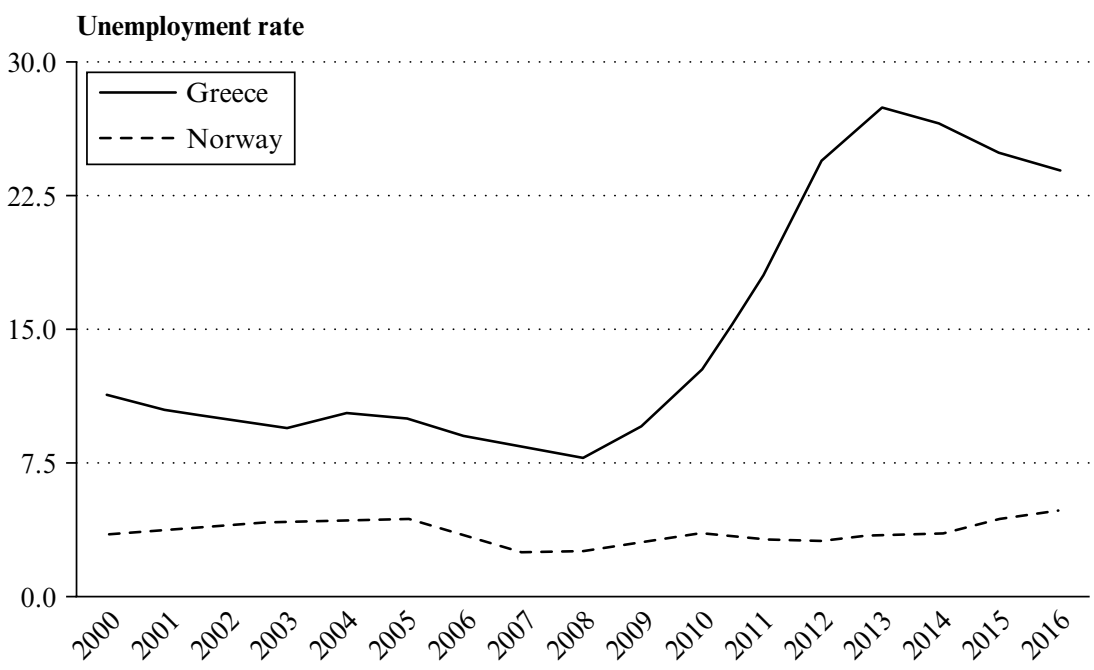

Source: TheGlobalEconomy.com, World Bank.

Figure 5A.2 Unemployment rate, Greece and Norway, 2000-16

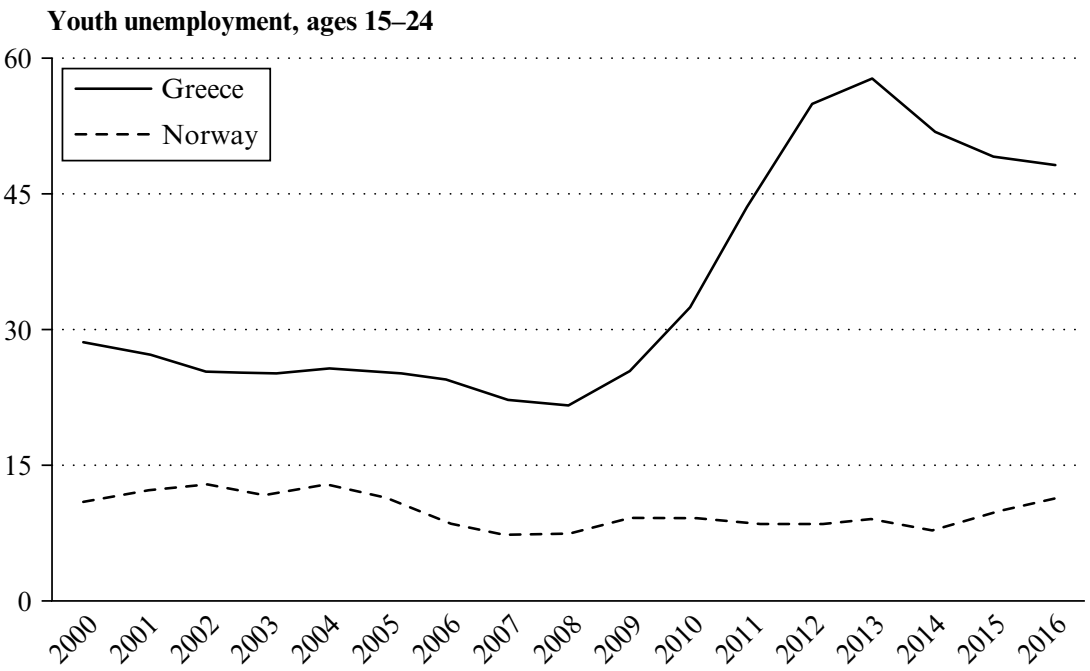

Source: TheGlobalEconomy.com, World Bank.

Figure 5A.3 Youth unemployment rate, Greece and Norway, 2000-16 
Marginal effects of ALMP by country and gender

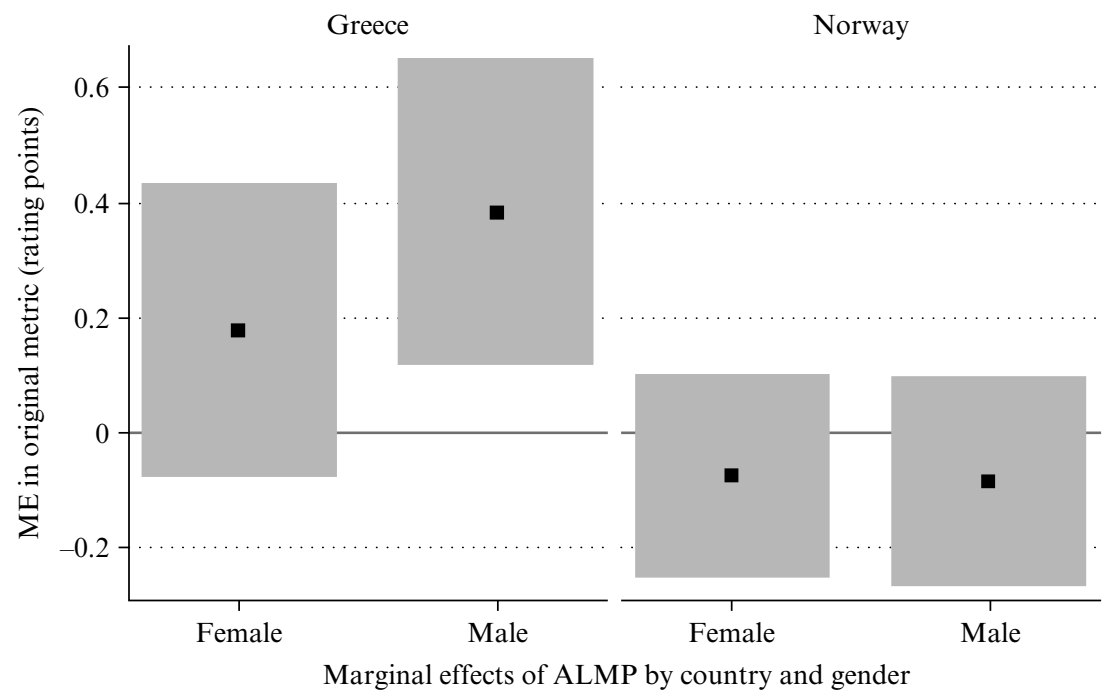

Source: NEGOTIATE employer survey.

Figure 5 A.4 Marginal effects of ALMP participation on recruiter ratings by country and gender 